\title{
Control of Papaya Ringspot Virus-Type W in Zucchini Squash by Cross-Protection in Brazil
}

J. A. M. Rezende and D. A. Pacheco, Associate Professor and Undergraduate Research Assistant, respectively, Departamento de Fitopatologia, Escola Superior de Agricultura "Luiz de Queiroz," Universidade de São Paulo, 13418-900 Piracicaba, São Paulo, Brazil

\begin{abstract}
Rezende, J. A. M., and Pacheco, D. A. 1998. Control of papaya ringspot virus-type W in zucchini squash by cross-protection in Brazil. Plant Dis. 82:171-175.

Two mild strains of papaya ringspot virus-type W (PRSV-W) were tested under greenhouse and field conditions to study the potential of cross-protection for control of zucchini squash mosaic. Protected plants of zucchini squash cultivars Caserta and Clarinda were challenged with three severe strains from different geographic regions of the country in tests carried out in the greenhouse. Challenge inoculations were done mechanically 10 and 20 days after the protective inoculation. The mild strains did not have a visible negative effect on the development of the plants and offered effective protection against the severe strains. Field tests of protected Caserta plants were carried out in Piracicaba County, São Paulo. Comparative evaluation based on the symptoms and development of protected and unprotected plants of zucchini squash showed that both mild strains effectively protected the plants against the effects of the severe strain present in the field. Yield of marketable fruits harvested from protected plants was only $10 \%$ less than that of the healthy plants in one field trial. Compared with the yield from plants infected with the severe strains, protected plants showed an increase of 511 and $633 \%$ in the number and weight of marketable fruits, respectively, in a test in 1994. In a second experiment in 1995, an increase of $327 \%$ in the number and $344 \%$ in the weight of marketable fruits was recorded. These studies demonstrate the effectiveness of cross-protection for the control of the mosaic disease caused by PRSV-W in zucchini squash and offer growers a method for large-scale application of this technology.
\end{abstract}

Additional keyword: Cucurbita pepo

Cucurbit plants can be affected by diseases induced by viral infection, which will cause significant reduction in yield. More than 20 viruses have been reported infecting plants of Cucurbitaceae in the field (14). In Brazil, eight viruses have been reported, including papaya ringspot virustype W (PRSV-W), watermelon mosaic virus 2 (WMV), zucchini yellow mosaic virus (ZYMV), cucumber mosaic virus (CMV), and squash mosaic virus (SMV). Although there are no recent studies regarding the frequency of incidence of these viruses in cucurbit species, past observations in commercial fields in the states of São Paulo (5), Pará (2), Rio Grande do Norte (12), Minas Gerais (19), and Ceará (13) and in the Distrito Federal (6) indicated that PRSV-W was predominant. Although estimates of crop loss are not available, PRSV-W is currently regarded as one of the most destructive pathogens infecting cucurbits in Brazil.

Corresponding author: J. A. M. Rezende; E-mail: jamrezen@carpa.ciagri.usp.br; Fax: 55-19-434 4839

Accepted for publication 23 September 1997.

Publication no. D-1997-1208-05R

(C) 1998 The American Phytopathological Society
All cucurbit species are susceptible to PRSV-W, but the most dramatic damage occurs in zucchini squash (Cucurbita pepo L.) because of its high sensitivity to the disease. Because of the absence of genetic sources of resistance to PRSV-W in $C$. pepo $(23,24)$ and the efficient dissemination of this potyvirus by several aphid species in a nonpersistent way, control of the disease in the field is very difficult. Most of the proposed methods for control rely on application of insecticide or mineral oil and the adoption of cultural practices, especially the use of reflective mulches, that are not effective where disease incidence is high $(1,3,4,17,30)$. Also, no transgenic zucchini squash resistant to PRSV-W has been developed (31). Hence, cross-protection with mild strains of PRSV-W could be a valuable alternative until resistant cultivars become available.

Cross-protection is a phenomenon in which plants systemically infected with one strain of a virus prevent the expression of a second, related strain of the same virus (7). Large-scale application of crossprotection has been reported for the control of tobacco mosaic virus (TMV) in tomato (Lycopersicon esculentum Mill.) in Europe $(8,25)$ and Japan (18), citrus tristeza virus (CTV) in citrus (Citrus sp.) in Brazil (16), and papaya ringspot virus-type $\mathrm{P}$ (PRSV-
P) in papaya (Carica papaya L.) in Taiwan $(34,35)$. Protection against ZYMV has been successful in field experiments with zucchini squash $(C$. pepo $)(11,32,33)$ and cantaloupe (Cucumis melo L.) (20).

Recently, two mild strains of PRSV-W, PRSV-W-1 and PRSV-W-2, were selected from blisters on mosaic leaves of zucchini squash plants systemically infected with a common strain of PRSV-W. Under greenhouse conditions, a high degree of protection was observed when both mild strains were used to protect zucchini squash (cultivar Caserta) against the parental severe strain of the virus (29). In this study, we report on the cross-protection effectiveness of PRSV-W mild strains under greenhouse and field conditions in the State of São Paulo, Brazil.

\section{MATERIAL AND METHODS}

Virus strains. Two mild strains (PRSVW-1 and PRSV-W-2), selected by Rezende et al. (29), and three severe strains isolated in Campinas (PRSV-W-C) and Botucatu (PRSV-W-B), State of São Paulo, and in Petrolina (PRSV-W-P), State of Pernambuco, were used in this study. Both mild strains induce temporary veinclearing in zucchini squash plants 7 to 10 days after inoculation. Thereafter, plants may show very mild mosaic or are symptomless. Symptoms induced by all three severe strains in zucchini squash are similar and are characterized by severe mosaic, leaf malformation, blisters, and stunting. Fruits from plants infected with the common strains are small and deformed and have dark green skin. All strains were maintained in plants of $C$. pepo 'Caserta' under greenhouse conditions.

Inoculation and host reaction to mild strains. Tissue samples from $C$. pepo 'Caserta' infected with PRSV-W-1 and PRSV-W-2 were separately ground in 0.02 M potassium phosphate buffer ( $\mathrm{pH} 7.0$ ), diluted 1:20. The extracts were rubbed on test plants predusted with 320-mesh Carborundum. Development of the infections by the mild strains was checked visually 7 to 10 days after inoculation and by a modified plate trapped antigen-enzyme-linked immunosorbent assay (PTA-ELISA) (15) with antiserum against PRSV-W obtained from J. Dale, Queensland University of Technology, Brisbane, Australia. ELISA reactions were recorded by an S960 ELISA reader (Metertech, Taiwan) at $A_{405}$. 
Cross-protection tests under greenhouse conditions. Zucchini squash seedlings of cultivars Caserta and Clarinda were mechanically inoculated at the cotyledonary stage with PRSV-W-1 or PRSV-W2. Infection was confirmed by PTA-ELISA 10 days after inoculation. The severe strains (PRSV-W-C, PRSV-W-B, and PRSV-W-P) were used for challenge inoculation by using crude leaf extracts diluted at $1 \mathrm{~g} / 10 \mathrm{ml}$. Challenge inocula were applied to the three upper fully expanded leaves of protected zucchini squash 10 and 20 days after protective inoculation with the mild strains. The following treatments were compared: (i) plants inoculated only with the mild strains; (ii) plants inoculated with the mild strains and separately challenged with the severe strains; (iii) plants mock inoculated with buffer and inoculated with the severe strains at the time of the challenge inoculation; and (iv) plants mock inoculated with buffer. Breakdown of cross-protection was judged by the appearance of severe symptoms in test plants, which were observed in the greenhouse for 4 weeks after challenge inoculation. Symptom severity and stunting were scored on a scale of 1 (mild symptoms) to 5 (severe mosaic, leaf malformation, and stunting).

Field trial 1. The first field trial was conducted in Piracicaba from 7 October to 9 December 1994. Seeds of zucchini squash Caserta were sown directly in the field in soil previously prepared with $3 \mathrm{~kg}$ of bovine manure and $200 \mathrm{~g}$ of N-P-K (4-148) per plant spot. As soon as germination occurred, the field was divided into five blocks containing 60 seedlings each. Blocks were divided into five plots containing 12 plants arranged in three rows with 1-m spacing between plants and rows. The following treatments were randomly applied to each block: (i) one plot of plants was inoculated with the mild strain PRSV-W-1; (ii) one plot of plants was inoculated with the mild strain PRSV-W-2; and (iii) three plots of plants were mock inoculated with buffer. The inocula were prepared from infected C. pepo 'Caserta,' and inoculation was done at the cotyledonary stage 2 days after germination. A random sample representing $20 \%$ of the plants inoculated with the mild strains was tested by PTA-ELISA 10 days after inoculation to confirm protective infection. Test plants were surrounded by a single row of uninoculated guard plants. Breakdown of cross-protection was evaluated weekly on the basis of the appearance of severe mosaic and stunting in protected plants compared with those naturally infected with the severe strain of PRSV-W. Fruits were harvested every other day during 30 days. Fruits separately harvested from plants of each treatment were classified as marketable or unmarketable on the basis of their appearance. All fruits of each class were separately weighed.
Field trial 2. The second field experiment was carried out at the same location from 25 October to 20 December 1995. The same experimental design described above was used. The following treatments were randomly applied to each block: (i) one plot of plants was inoculated with the mild strain PRSV-W-1; (ii) one plot of plants was inoculated with the mild strain PRSV-W-2; (iii) two plots of plants were inoculated with the common strain PRSV$\mathrm{W}-\mathrm{C}$; and (iv) one plot of plants was mock inoculated with buffer. The third treatment was introduced in order to increase the local source of the severe strain, since the experimental field was located far from cucurbit crops. All inoculations were done at the cotyledonary stage, and infection was tested as before. Evaluations of breakdown of cross-protection and yield were done as described for the first trial. Fruits were harvested every other day during 14 days.

Mass inoculation. An efficient method of mass inoculation of zucchini squash seedlings is essential for commercial application of cross-protection. Pressure-spray inoculation was evaluated with a paint spray gun attached to an air compressor (Jet Master II, Schulz, Joinville, SC, Brazil). Inoculum of the mild strain PRSVW-1 was prepared from C. pepo 'Caserta' inoculated 2 to 3 weeks previously. Leaves were ground in a blender in cold $0.02 \mathrm{M}$ potassium phosphate buffer, $\mathrm{pH} 7.0$, at dilutions $(\mathrm{g} / \mathrm{ml})$ of 1:50, 1:100, 1:150, and 1:200. The extracts were strained through cheesecloth and then mixed with Carborundum (320 mesh, $12.5 \mathrm{~g} / 0.5$ liter) in a plastic container connected to the spray gun. Plants were inoculated with a constant pressure of $2.8 \mathrm{~kg} \mathrm{~cm}^{-2}$. The distance between the seedlings and the spray gun was $5 \mathrm{~cm}$.

Seeds of $C$. pepo 'Caserta' were sown in trays with 128 cells containing Plantmax, a commercial substrate mixture (Eucatex Mineral, Paulinia, SP, Brazil). Seedlings were inoculated 2 to 3 days after germination at the cotyledonary stage. During inoculation, the spray gun was kept moving slowly back and forth to ensure that each seedling was sprayed twice. Three days after inoculation, $20 \%$ of the seedlings from each tray were transplanted to pots with a mixture of soil and manure to allow further growth of the plants. Infection was checked with PTA-ELISA 10 days later.

Data analysis. Data were subjected to analysis of variance with the SAS (SAS Institute, Cary, NC) general linear model procedure. Means were separated by Fisher's least significant difference test.

\section{RESULTS}

Greenhouse tests. Two independent experiments of cross-protection effectiveness of PRSV-W-1 and PRSV-W-2 against three severe strains of PRSV-W (PRSV-W$\mathrm{C}$, PRSV-W-B, and PRSV-W-P) were conducted with the cultivars Caserta and Clar- inda. Eight plants of each cultivar were tested for each mild strain-severe strain combination. Unprotected plants of Caserta and Clarinda used as controls in each challenge inoculation showed severe symptoms 10 to 12 days after inoculation. Test plants of both cultivars inoculated with mild strain PRSV-W-1 were $100 \%$ protected against double-challenge inoculation with all three severe strains. Protection with mild strain PRSV-W-2 was almost as effective as that with PRSV-W-1, except for one plant of Clarinda, which showed severe symptoms after the first challenge inoculation. Development of plants protected with mild strains was similar to that of the healthy controls.

Field trials. Plants used in the field experiments were mechanically inoculated 2 days after germination. The $20 \%$ of seedlings inoculated with both mild strains and tested by PTA-ELISA showed positive readings 10 days after inoculation.

Both field trials were severely affected by natural infection of some plants with an apparently new species of the genus Tospovirus, family Bunyaviridae $(22,26)$, which caused the death of approximately 30 and $20 \%$ of the test plants in field trials 1 and 2 , respectively. Because of this undesirable natural contamination, only plants that did not show any characteristic symptoms caused by this tospovirus until the end of the experiments were considered for crossprotection and yield evaluations.

Tests for the presence of other cucurbit viruses, especially CMV, ZYMV, and WMV, were not done. However, a current survey for viruses affecting cucurbit

Table 1. Frequency of protected and unprotected plants of zucchini squash cultivar Caserta showing severe symptoms after 45 to 50 days in the field

\begin{tabular}{lrc}
\hline & $\begin{array}{c}\text { Plants } \\
\text { Plants } \\
\text { shalu- } \\
\text { showing } \\
\text { severe } \\
\text { symp- } \\
\text { (no. } \\
\text { toms } \\
\text { (no.) }^{\mathbf{z}}\end{array}$ \\
\hline Treatment $^{\mathbf{y}}$ & & \\
\hline Field trial 1 & & \\
PRSV-W-1 (cotyledon) & 41 & 0 \\
PRSV-W-2 (cotyledon) & 47 & 2 \\
Unprotected & 125 & 46 \\
Field trial 2 & & \\
PRSV-W-1 (cotyledon) & 51 & 0 \\
PRSV-W-2 (cotyledon) & 46 & 6 \\
PRSV-W-C (cotyledon) & 104 & 104 \\
Unnrotected & 44 & 28 \\
\hline
\end{tabular}

y Zucchini squash seeds were sown directly in the field. Seedlings were mechanically inoculated with papaya ringspot virus-type W (PRSV-W) mild strains PRSV-W-1 and PRSVW-2 (field trials 1 and 2) and severe strain PRSV-W-C (field trial 2) 2 days after germination at the cotyledonary stage.

${ }^{\mathrm{z}}$ Individual plants of each treatment were scored for leaf symptom severity and stunting every 10 days. Symptoms were scored on a scale of 1 (mild) to 5 (severe mosaic, leaf malformation, and stunting). 
crops in the State of São Paulo have shown that the most prevalent viruses in zucchini squash have been PRSV-W, ZYMV, and a recently identified tospovirus. Also, ZYMV has not yet been found in samples collected in Piracicaba (unpublished results).

Natural incidence and spread of the common strain of PRSV-W was relatively low in field trial 1 (Table 1). Only $36.8 \%$ of healthy controls showed severe symptoms at the end of the test. Such low incidence of severely infected controls apparently resulted from the location of the experimental field, which is in the university campus area and far way from cucurbit crops. Incidences of PRSV-W close to $100 \%$ have been frequently observed in commercial crops, especially during the summer. In spite of the low incidence of disease in the field, it was enough to demonstrate that protection with mild strains of PRSV-W was effective. None of the 41 plants protected with PRSV-W-1 showed severe symptoms during 50 days in the field. Only two of 47 plants protected with PRSV-W-2 showed severe symptoms during the period of the test. In field trial 2, the incidence of severe infection of unprotected plants reached $63.6 \%$ after 45 days (Table 1). Once again, all 51 plants protected with PRSV-W-1 remained symptomless until the end of the test. Severe symptoms were recorded in six of 46 plants protected with mild strain PRSV-W2. Development of protected, symptomless plants was similar to that of the healthy controls, while unprotected plants and those infected with the common strain showed severe mosaic, leaf malformation, and stunting (Fig. 1).
Beneficial effects of mild-strain protection were also obtained with respect to fruit numbers, weight, and marketability in both experiments (Table 2). Since $63.2 \%$ of unprotected plants in field trial 1 remained healthy until the end of the experiment (i.e., tested negative in PTA-ELISA; data not shown), yield from unprotected, symptomatic plants and unprotected, asymptomatic plants were grouped separately for further comparison. Plants protected with mild strains PRSV-W-1 and PRSV-W-2 produced slightly less fruit than those that stayed healthy (asymptomatic) for the period of the test. Yields of marketable fruits from plants that became naturally infected with the common strain of PRSV-W were significantly lower than those of protected and healthy plants.
While protected and healthy plants gave a similar low yield of unmarketable fruits, $75.5 \%$ of fruits produced by unprotected, symptomatic plants showed dark skin, distortion and surface protuberances (Fig. 2), making them unmarketable.

The average yield of marketable fruits harvested from protected plants in field trial 2 was similar to that recorded in the first trial. Also, these plants gave a very low percentage of unmarketable fruits compared with the unprotected control plants. Plants inoculated with the common strain PRSV-W-C at the cotyledonary stage did not produce commercial fruits (the devastating effect of the disease on zucchini squash when infection occurs early in the growing season is well-known).

Table 2. Comparison of yields of marketable (M) and unmarketable (NM) fruits from protected and unprotected plants of zucchini squash cultivar Caserta grown in the field at Piracicaba, São Paulo, Brazil

\begin{tabular}{|c|c|c|c|c|}
\hline \multirow[b]{2}{*}{ Treatment ${ }^{y}$} & \multicolumn{2}{|c|}{$\begin{array}{l}\text { Mean number } \\
\text { of fruits/plant }{ }^{\mathrm{z}}\end{array}$} & \multicolumn{2}{|c|}{$\begin{array}{l}\text { Mean weight (kg) } \\
\text { of fruits/plant }\end{array}$} \\
\hline & M & NM & M & NM \\
\hline \multicolumn{5}{|l|}{ Field trial 1} \\
\hline PRSV-W-1 (cotyledon) & $7.1 \mathrm{a}$ & $0.6 \mathrm{~b}$ & $2.1 \mathrm{a}$ & $0.3 \mathrm{~b}$ \\
\hline PRSV-W-2 (cotyledon) & $6.2 \mathrm{a}$ & $1.0 \mathrm{~b}$ & $1.7 \mathrm{a}$ & $0.4 \mathrm{~b}$ \\
\hline Unprotected, symptomatic & $1.3 \mathrm{~b}$ & $4.0 \mathrm{a}$ & $0.3 \mathrm{~b}$ & $1.3 \mathrm{a}$ \\
\hline Unprotected, asymptomatic & $7.4 \mathrm{a}$ & $1.0 \mathrm{~b}$ & $2.1 \mathrm{a}$ & $0.5 \mathrm{~b}$ \\
\hline \multicolumn{5}{|l|}{ Field trial 2} \\
\hline PRSV-W-1 (cotyledon) & $6.4 \mathrm{a}$ & $0.4 \mathrm{~b}$ & $2.2 \mathrm{a}$ & $0.1 \mathrm{~b}$ \\
\hline PRSV-W-2 (cotyledon) & $5.4 \mathrm{a}$ & $0.9 \mathrm{~b}$ & $1.9 \mathrm{a}$ & $0.3 \mathrm{~b}$ \\
\hline PRSV-W-C (cotyledon) & $0.0 \mathrm{c}$ & $0.3 \mathrm{~b}$ & $0.0 \mathrm{c}$ & $0.1 \mathrm{~b}$ \\
\hline Unprotected & $1.8 \mathrm{~b}$ & $2.8 \mathrm{a}$ & $0.6 \mathrm{~b}$ & $0.9 \mathrm{a}$ \\
\hline
\end{tabular}

Zucchini squash seeds were sown directly in the field. Seedlings were mechanically inoculated with papaya ringspot virus-type W (PRSV-W) mild strains PRSV-W-1 and PRSV-W-2 (field trials 1 and 2) and severe strain PRSV-W-C (field trial 2) 2 days after germination at the cotyledonary stage.

Means within a column followed by the same letter do not differ statistically $(P<0.01)$, according to Fisher's least significant difference test. Field trials were analyzed separately.

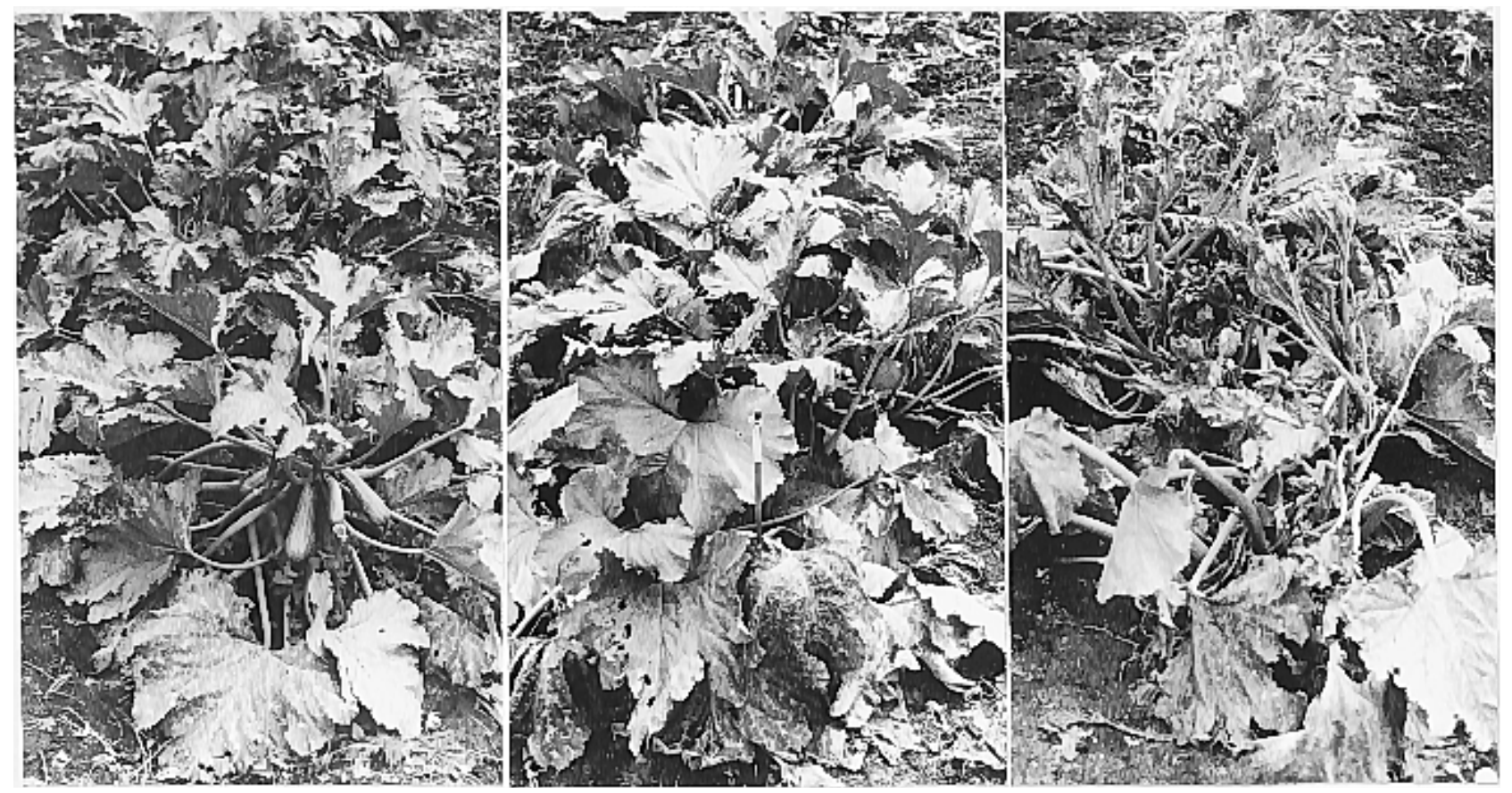

Fig. 1. Field trial 1. Healthy zucchini plants (left) and protected plants (center) show normal growth, and unprotected plants (right) show severe mosaic, leaf malformation, and stunting. 
Mass inoculation. The transmission rate of both mild strains from Caserta to Caserta plants by manual rubbing was $100 \%$. Also, $100 \%$ infection of zucchini squash was found when seedlings were sprayinoculated at the cotyledonary stage with different concentrations of the inoculum (1:50, 1:100, 1:150, and 1:200) at constant pressure $\left(2.8 \mathrm{~kg} \mathrm{~cm}^{-2}\right)$ and distance $(5 \mathrm{~cm})$ (data not shown). No damage to leaves of inoculated plants was observed.

\section{DISCUSSION}

We have shown that the effectiveness of cross-protection by the mild strains PRSVW-1 and PRSV-W-2 under greenhouse conditions is independent of the geographic origin of the severe strains used. Both protecting strains originated from the common strain PRSV-W-C and offered excel(PRSV-W-C and PRSV-W-B) from the State of São Paulo and one (PRSV-W-P) from the State of Pernambuco, located approximately 2,500 km from São Paulo. Previous experiments showed that protection was also effective when protected plants were challenged with the common strain PRSV-W-C by means of aphid inoculation (29). Both mild strains caused almost imperceptible symptoms on zucchini squash cultivars Caserta and Clarinda and did not have an apparent effect on the development of the plants. Only one prosymptoms after it was challenged with the common strain PRSV-W-P. This plant tested positive on PTA-ELISA prior to the challenge inoculation, and so the symptom intensification could be the result of breakdown of cross-protection or reversion of the mild strain to a severe form. lent protection against two common strains tected plant of Clarinda showed severe

Cross-protection was also effective under field conditions. None of the 92 Caserta plants protected with the mild strain PRSV-W-1, evaluated in both trials, developed severe mosaic and stunting during the test period. Approximately $4 \%$ of the plants protected with mild strain PRSV-W2 in field trial 1 and $13 \%$ in field trial 2 developed severe symptoms late in the growing season (Table 1). It is not known whether this was because those plants were not infected with the protective strain, reversion of the mild strain to a severe strain occurred, or there was a breakdown of protection, as has been reported for PRSV-P in papaya plants (34). Studies carried out by Rezende and Pacheco (28) on the stability of both mild strains of PRSV-W, based on symptoms induced on zucchini squash plants, favors the hypothesis that symptom intensification could be associated with reversion of the mild strain to a severe strain.

Whatever the reason for the appearance of protected plants with severe mosaic may be, it had little effect on overall yield and fruit quality. In field trial 1, it was possible to determine the effect of the mild strains alone on fruit yield and quality, because $63.2 \%$ of unprotected plants remained healthy (asymptomatic) during the period of the test. The yield of marketable fruits harvested from protected plants was approximately $10 \%$ less than that produced by healthy plants. This yield loss is to be expected, since the protected plants are in fact infected with a strain of the virus. Although the protective virus strains cause no apparent disease and do not seem to affect plant development, probably some metabolites synthesized by the protected plants are diverted to virus synthesis, re-

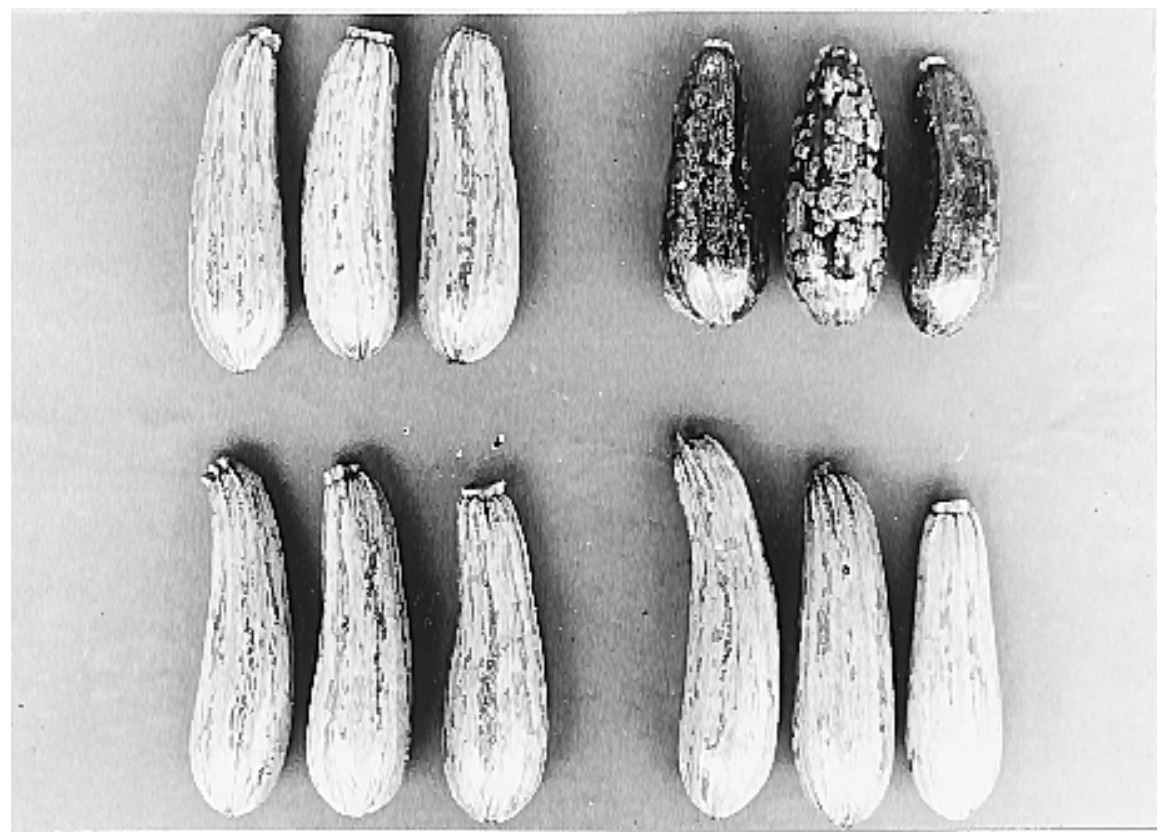

Fig. 2. Clockwise from upper left: zucchini fruits from healthy plants, from plants infected with common strains of papaya ringspot virus-type W (PRSV-W), from plants protected by inoculation with PRSV-W-1, and from plants protected by inoculation with PRSV-W-2. sulting in lower fruit yield. This level of yield loss is acceptable, especially when the yield of marketable fruits from protected plants is compared with that from plants naturally infected with the common strain. In this case, the average increase in number and weight of marketable fruits was 511 and $633 \%$ in the field trial 1 , respectively, and 327 and $344 \%$ in field trial 2 , respectively.

Cross-protection with both mild strains combined with the tolerance to PRSV-W found in long-neck squash (C. moschata (Duchesne) Duchesne ex Poir. cv. Menina Brasileira) (10) was also evaluated under greenhouse and field conditions. Protection was very effective, and the average yield (weight) of marketable fruits from protected plants was approximately 33\% higher than that of plants naturally infected in the field. The combination of mild strain protection and tolerance of Menina Brasileira provided better disease control with a significant increase in fruit yield (unpublished data). Greenhouse tests with watermelon (Citrullus lanatus (Thunb.) Matsum \& Nakai cvs. Charleston Gray and Crimson Sweet) and the hybrid Tetsukabuto $(C$. moschata $\times C$. maxima Duchesne) have also shown that the mild strains PRSV-W-1 and PRSV-W-2 offer complete protection against all three severe strains (unpublished data). Field evaluations are under way.

The usefulness of cross-protection in preserving plant yield has also been demonstrated for the control of a mosaic disease caused by ZYMV in some cucurbit species. Lecoq et al. (11) reported in France that two cultivars of protected zucchini squash had yields 14.7 times higher than those of unprotected and severely diseased plants. In Taiwan, Wang et al. (33) showed that the same mild strain of ZYMV tested in France controlled the disease in cucurbits in the field and gave an increase in yield of 116 and $1,256 \%$ in the first and second years, respectively. Walkey et al. (32) reported success with cross-protected $C$. pepo that resulted in an increase in marketable fruit of 0 to $43 \%$ in the first test and 56 to $63 \%$ in another study. Perring et al. (20) showed that cross-protection with the mild strain of ZYMV conserved marketable yield of cantaloupe by nearly $75 \%$ in California.

Because zucchini squash is normally propagated by seeds, an efficient method for inoculation of a large number of seedlings must be available to achieve practical application of cross-protection. The method of pressure-spray inoculation achieved $100 \%$ infection with inoculum at dilutions of $1: 50$ to $1: 200$. Since this technology is inexpensive, inoculum diluted 1:50 has been recommended to assure the best protective inoculation. One liter of such inoculum is enough to inoculate five trays with a total of 640 seedlings. At the planting rate of 10,000 plants per hectare, approximately 16 liters of inoculum or $320 \mathrm{~g}$ of fresh tissue infected with the mild strain 
would be required for preimmunization of the seedlings needed for 1 ha. Inoculation of cantaloupe with a mild strain of ZYMV required a $10 \%$ solution of inoculum sprayed at $2.1 \mathrm{~kg} \mathrm{~cm}^{-2}$ to obtain nearly $80 \%$ infection (20). Researchers in that study estimated that $33.6 \mathrm{~kg}$ of leaf material would be required for each hectare sprayed, assuming a planting rate of 16,800 melons per hectare.

The successful results of the field tests and the great stability shown by mild strain PRSV-W-1 (28) suggest that cross-protection to control PRSV-W in zucchini squash can be an effective practice. On the basis of these initial trials, some small growers and one nursery company are already producing zucchini squash seedlings preimmunized with PRSV-W-1 for commercial use, and some growers have expressed satisfaction with the result they have obtained with their protected crop.

Cross-protection, viewed as a biological method, offers several advantages for viral disease control. It does not pollute, does not constitute a risk to growers or consumers, and does not interfere with any other practice applied for disease management. Furthermore, application is simple and inexpensive. However, several authors have pointed out some risks associated with the use of mild strains in the field, such as the synergistic effect with other viruses, breakdown of cross-protection, and mutation of the mild strain to severe forms $(9,21,27)$. In the present study, zucchini squash plants protected with mild strains PRSV-W-1 and PRSV-W-2 were challenged with common strains of ZYMV and WMV under greenhouse conditions. No protection against either virus was observed. Also, no synergistic effect was noticed on the basis of symptom expression and plant development (unpublished results). Cross-protection tests carried out in France and Taiwan for the control of ZYMV also showed mixed infection with WMV, PRSV-W, and CMV, but there was no reference to synergistic effect $(11,33)$.

Although there are risks involved in the use of mild strains for controlling PRSV-W in zucchini squash, at the present time it is the only effective method for preserving an economical yield, especially in those areas were PRSV-W is prevalent and infects a large number of plants during the growing season. Cross-protection can be recommended until resistant cultivars, obtained by conventional breeding or genetic transformation, become available to growers.

\section{AKNOWLEDGMENTS}

This research was supported by a grant to J. A. M. Rezende from FAPESP (Fundação do Amparo à Pesquisa no Estado de São Paulo, Brazil), Proc. 94/2444-0. We thank E. W. Kitajima, ESALQ/ USP, for critical review of the manuscript; Jim Starr, Texas A\&M University, for assistance with the data analysis; and Margaret P. Wagner for English review.

\section{LITERATURE CITED}

1. Adlerz, W. C., and Everett, P. H. 1968. Aluminum foil and white polyethylene mulches to repel aphids and control watermelon mosaic. J. Econ. Entomol. 61:1276-1279.

2. Albuquerque, F. C., Ikeda, H., and Costa, A. S. 1972. Ocorrência do vírus do mosaico da melancia (Citrullus vulgaris Schrad.) em plantações de melão (Cucumis melo L.) na região de Belém-PA. (Abstr.) Rev. Olericult. 12:94.

3. Brown, J. E., Dangler, J. M., Woods, F. M., Tilt, K. M., Henshaw, M. D., Griffey, W. A., and West, M. S. 1993. Delay in mosaic virus onset and aphid vector reduction in summer squash grown on reflective mulches. HortScience 28:895-896

4. Chalfant, R. B., Jaworski, C. A., Jonhson, A. W., and Sumner, D. R. 1977. Reflective film mulches, millet barriers, and pesticides effect on watermelon mosaic virus, insects, nematodes, soil borne fungi, and yield of yellow summer squash. J. Am. Soc. Hortic. Sci. 102: 11-15.

5. Costa, A. S., Kitajima, E. W., and Nagai, H. 1972. Alguns vírus que afetam o pepino (Cucumis sativus L.) em São Paulo. (Abstr.) Rev. Olericult. 12:100-101.

6. Cupertino, F. P., Costa, C. L., Kitajima, E. W., Mattos, J. K. A., and Araujo, M. T. 1974. Vírus de cucurbitáceas no D. Federal. (Abstr.) Fitopatologia 9:51.

7. Dodds, J. A. 1982. Cross-protection and interference between eletrophoretically distinct strains of cucumber mosaic virus in tomato. Virology 118:235-240.

8. Fletcher, J. T. 1978. The use of avirulent strains to protect plants against the effects of virulent strains. Ann. Appl. Biol. 89:110-114.

9. Fulton, R. W. 1986. Practices and precautions in the use of cross-protection for plant virus disease control. Annu. Rev. Phytopathol. 24: 67-81.

10. Kuabara, M. Y., Salcedo, M. J. G., and Costa, C. P. 1987. Fontes de resistencia ao vírus do mosaico da melancia-1 (WMV-1) em abóbora. Hortic. Bras. 5:20-21.

11. Lecoq, H., Lemaire, J. M., and Wipf-Scheibel, C. 1991. Control of zucchini yellow mosaic virus in squash by cross-protection. Plant Dis. 75:208-211.

12. Lima, J. A. A., Fernandes, E. R., and Mendes, M. L. 1980. Identificação sorológica de "watermelon mosaic virus 1 " em cucurbitáceas cultivadas e nativas do Rio Grande do Norte. (Abstr.) Fitopatol. Bras. 5:414.

13. Lima J. A. A., and Vieira, A. C. 1992. Distribuição do vírus do mosaico da abóbora em municípios cearences e gama de hospedeiros de um isolado. Fitopatol. Bras. 17:112-114.

14. Lovisolo, O. 1980. Virus and viroid diseases of cucurbits. Acta Hortic. 88:33-71.

15. Mowat, W. P., and Dawson, S. 1987. Detection of plant viruses by ELISA using crude sap extracts and unfractionated antisera. J. Virol. Methods 15:233-247.

16. Müller, G. W., and Costa, A. S. 1977. Tristeza control in Brazil by preimmunization with mild strains. Proc. Int. Soc. Citric. 3:868-872.

17. Orozco, S. M., Lopez, A. O., Perez, Z. O., and Delgadillo, S. F. 1994. Effect of transparent mulch, floating row covers and oil sprays on insect populations, virus disease and yield of cantaloupe. Biol. Agric. Hortic. 10:229-234.

18. Oshima, N. 1975. The control of tomato mosaic disease with attenuated virus of a tomato strain of TMV. Rev. Plant Prot. Res. 8:126-135.

19. Pavan, M. A., Carvalho, M. G. and Fernandes, J. J. 1989. Distribuição do vírus do mosaico da melancia (papaya ringspot virus-W), nas principais regiões produtoras de pepino $(\mathrm{Cucu}-$ mis sativus) e abobrinha (Cucurbita pepo) de Minas Gerais. Fitopatol Bras. 14:84-85.
20. Perring, T. M., Farrar, C. A., Blua, M. J. Wang, H. L., and Gonsalves, D. 1995. Crossprotection of cantaloupe with a mild strain of zucchini yellow mosaic virus: Effectiveness and application. Crop Prot. 14:601-606.

21. Posnette, A. F., and Todd, J. M. 1955. Virus diseases of cacao in West Africa. IX. Strain variant and interference in virus 1A. Ann. Appl. Biol. 43:433-453.

22. Pozzer, L., Resende, R. O., Bezerra, M. I. Nagata, T., Lima, M. I., Kitajima, E. W., and De Ávila, A. C. 1996. Zucchini lethal chlorotic virus (ZLCV), a proposed new species in the Tospovirus genus. (Abstr.) Fitopatol. Bras. 21(supl.):432.

23. Provvidenti, R. 1990. Viral diseases and genetic sources of resistance in Cucurbita species. Pages 427-435 in: Biology and Utilization of the Cucurbitaceae. D. M. Bates, R W. Robinson and C. Jeffrey eds. Cornell University Press, Ithaca, NY.

24. Provvidenti, R., and Hampton, R. O. 1992. Sources of resistance to virus in the Potyviridae. Pages 189-211 in: Arch. Virol. Suppl. 5.

25. Rast, A. T. B. 1972. MII-16, an artificial symptomless mutant of tobacco mosaic virus for seedling inoculation on tomato crops. Neth. J. Plant Pathol. 28:110-112.

26. Rezende, J. A. M., Galleti, S. R., Pozzer, L., Resende, R. O., De Ávila, A. C., and Scagliusi, S. M. M. 1997. Incidence, biological and serological characteristics of a tospovirus infecting experimental fields of zucchini in São Paulo State, Brazil. Fitopatol. Bras. 22:92-95

27. Rezende, J. A. M., and Müller, G. W. 1995. Mecanismos de proteção entre vírus e controle de viroses de vegetais por premunização. Rev. Anu. Patol. Plantas 3:185-226.

28. Rezende, J. A. M., and Pacheco, D. A. 1997. Estabilidade de isolados fracos premunizantes do vírus do mosaico do mamoeiro-estirpe melancia. Fitopatol. Bras. 22:64-68.

29. Rezende, J. A. M., Yuki, V. A., Vega, J., Scagliusi, S. M. M., Borba, L. F., and Costa, A. S. 1994. Isolados fracos do potyvirus causador do mosaico da abobrinha presentes em bolhas atuam na premunização. Fitopatol. Bras. 18:55-61.

30. Summers, C. G., Stapleton, J. J., Newton, A. S., Duncan, R. A., and Hart, D. 1995. Comparison of sprayable and film mulches in delaying the onset of aphid-transmitted virus deseases in zucchini squash. Plant Dis. 79: 1126-1131.

31. Tricoli, D. M., Carney, K. J., Russell, P. F., McMaster, J. R., Groff, D. W., Hadden, K. C., Himmel, P. T., Hubbard, J. P., Boeshore, M L., and Quemada, H. D. 1995. Field evaluation of transgenic squash containing single or multiple coat protein gene constructs for resistance to cucumber mosaic virus, watermelon mosaic virus 2, and zucchini yellow mosaic virus. Bio/Technology 13:1458-1465.

32. Walkey, D. G. A., Lecoq, H. L., Collier, R., and Dobson, S. 1992. Studies on the control of zucchini yellow mosaic virus in courgettes by mild strain protection. Plant Pathol. (London) 41:762-771

33. Wang, H.-L., Gonsalves, D., Provvidenti, R. and Lecoq, H. L. 1991. Effectiveness of crossprotection by a mild strain of zucchini yellow mosaic virus in cucumber, melon, and squash. Plant Dis. 75:203-207.

34. Wang, H.-L., Yeh, S.-D., Chiu, R.-J., and Gonsalves, D. 1987. Effectiveness of crossprotection by mild mutants of papaya ringspot virus for control of ringspot disease of papaya in Taiwan. Plant Dis. 71:491-497.

35. Yeh, S.-D., Gonsalves, D., Wang, H.-L., Namba, R., and Chiu, R.-J. 1988. Control of papaya ringspot virus by cross protection. Plant Dis. 72:375-380. 